\title{
A Conceptual Modeling Approach to Health-Related Urban Well-Being
}

\author{
Malte von Szombathely ${ }^{1, *}$, Myriam Albrecht ${ }^{1}$, Dejan Antanaskovic ${ }^{2}$, Jobst Augustin ${ }^{3}$, \\ Matthias Augustin ${ }^{3}$, Benjamin Bechtel ${ }^{1}$, Thomas Bürk ${ }^{1}$, Jana Fischereit ${ }^{4}$, David Grawe ${ }^{4}$, \\ Peter Hoffmann ${ }^{5}$, Giedrius Kaveckis ${ }^{1}$, Anne Caroline Krefis ${ }^{3}$, Jürgen Oßenbrügge ${ }^{1}$, \\ Jürgen Scheffran ${ }^{1}$ and K. Heinke Schlünzen ${ }^{4}$
}

1 Institute of Geography, Centrum für Erdsystemforschung und Nachhaltigkeit (CEN), Universität Hamburg, Bundesstr. 55, 20146 Hamburg, Germany; myriam.albrecht@uni-hamburg.de (M.A.);

benjamin.bechtel@uni-hamburg.de (B.B.); thomas.buerk@uni-hamburg.de (T.B.);

giedrius.kaveckis@uni-hamburg.de (G.K.); juergen.ossenbruegge@uni-hamburg.de (J.O.);

juergen.scheffran@uni-hamburg.de (J.S.)

2 Institute of River \& Coastal Engineering, Hamburg University of Technology, Denickestr. 22,

21073 Hamburg, Germany; dejan.antanaskovic@tuhh.de

3 Institute for Health Care Research in Dermatology and Nursing (IVDP), University Medical Center Hamburg-Eppendorf (UKE), Gebäude West 38 (W38), Martinistr. 52, 20246 Hamburg, Germany; jo.augustin@uke.de (J.A.); m.augustin@uke.de (M.A.); a.krefis@uke.de (A.C.K.)

4 Meteorological Institute, Centrum für Erdsystemforschung und Nachhaltigkeit (CEN), Universität Hamburg, Bundesstr. 55, 20146 Hamburg, Germany; jana.fischereit@uni-hamburg.de (J.F.); david.grawe@uni-hamburg.de (D.G.); heinke.schluenzen@uni-hamburg.de (K.H.S.)

5 Department of Mathematics, Centrum für Erdsystemforschung und Nachhaltigkeit (CEN), Universität Hamburg, Bundesstr. 55, 20146 Hamburg, Germany; peter.hoffmann@uni-hamburg.de

* Correspondence: malte.szombathely@uni-hamburg.de; Tel.: +49-040-42838-5202

Academic Editor: Michael Peter Smith

Received: 10 February 2017; Accepted: 9 May 2017; Published: 12 May 2017

\begin{abstract}
In cities, social well-being faces obstacles posed by globalization, demographic and climate change, new forms of social organization, and the fragmentation of lifestyles. These changes affect the vulnerability of city societies and impact their health-related urban well-being (UrbWellth). The conceptual model introduced in this paper systematizes the relevant variables while considering previous research, and establishes the target value UrbWellth. The model differs from existing approaches mainly in the analytical distinctions it suggests. These allow us to group the relevant urban influence variables into four sectors and enable a more general and abstract consideration of health-related urban relations. The introduction of vulnerability as a filter and transfer function acts as an effect modifier between UrbWellth and the various urban variables.
\end{abstract}

Keywords: conceptual model; urban well-being; urban health; multiple stressors; vulnerability; UrbWellth

\section{Introduction}

In the face of an inexorable increase in the number of people living in densely populated urban areas worldwide, the ability to understand the city's impact on human health and develop criteria for evaluating public health policies in urban contexts will be increasingly important [1]. Cities are constantly expanding nearly everywhere, even in regions of demographic decline. Obviously, cities promise a better life for the majority of citizens, and this persistent promise is the main driver of rural-urban migration and urban population growth. It is easy to enumerate the challenges posed by rapid urbanization, such as environmental stressors, mobility issues or socioeconomic polarization. 
When urban planning does not keep up with the speed of urbanization, urban growth may lead to "rapid sprawl, pollution, and environmental degradation, together with unsustainable production and consumption patterns" [2]. Underlying drivers like demographic change, climate change, and new forms of social organization and lifestyles impact this situation and act as additional risk multipliers, accelerating urban vulnerability [3-5]. If the 21st century is a century of cities, the issue of health-related well-being in urban areas will need to be afforded growing attention in both academic work and public intervention. Since cities are changing continuously and dynamically, our scientific concepts and approaches will need to consider these changes: "Health inequities within and between countries reflect economic and social divisions across society. As economic pressures bite and health care costs rise, the risk of exclusion increases, too often leaving behind those with the greatest health needs" [6].

Our paper aims to address two issues. First, we provide an overview of existing conceptions of urban health in order to outline the status quo. There has been a remarkable amount of work on this issue, but we contend that at least two factors have been largely overlooked. We argue that we need better conceptions capable of addressing the complexity of urban structures and dynamics; we also need to better interface with debates surrounding urban issues from the perspective of global (climate) change and transition research. We offer our own conception of urban health-related well-being (UrbWellth, see Section 2.2 for definition). With this conceptual model we also intend to integrate elements that have been previously overlooked like vulnerability as well as empirical evidence for those components of health-related well-being that form single and multiple stressors. Thus, health may be constructed as a function of a variety of environmental, social and individual variables [5,7].

Section 2 outlines our approach and its theoretical foundations, combining environmental health burdens and stressors with social and morphological characteristics of cities. We identify potentials and risks that may have an influence on urban health. The model refers to concepts and findings taken from the social sciences, urban planning, meteorology, epidemiology and geography. Recent studies from these fields are reviewed in Section 3 to yield an overview of the most important influence variables and interrelations that impact urban health and urban lifestyle. We will discuss the model's implications in Section 4.

\section{Health-Related Urban Well-Being-Conceptual Considerations}

\subsection{Conceptions of Urban Health}

Even though the healthy cities movement was established more than 30 years ago [8], its aims and approaches are more important than ever. From the beginning, its goal was not to promote particular actions but rather to advocate continuous improvement: "A healthy city is one that is continually creating and improving those physical and social environments and expanding those community resources which enable people to mutually support each other in performing all the functions of life and developing to their maximum potential" (emphasis added) [9]. We proceed from the assumption that the success of healthy urban societies depends on an overall understanding of the complex factors that influence urban health and the interrelationships between them. Therefore, our own model builds upon previously developed models. Over the last decades, several healthy city models have been discussed that vary in complexity and systematization, depending on their perspectives, background and scientific aims [10-12].

One of the first models was suggested by Hancock in 1986 and is called the "mandala of health". It introduced a basic separation between society and environment/biosphere [13]. Coutts interpreted nature in this approach as a container for the built city [14]. The biosphere is thus considered to be "the ultimate determinant of health" [15]. Hancock's overlapping cultural lens that goes beyond differences on a neighborhood level is fairly unique for models of public health. On the whole, all the influences on health revolve around the (health of the) individual human being.

The model by Evans and Stoddart, the "Ecological relationship of physical environment and health", makes a distinction between physical and social environment as well as the individual [16]. 
Genetic preconditions for diseases are mentioned and well-being is introduced as a target variable related to health. Still, no influence of the social world and no direct connection between well-being and diseases are established. With its feedback loop from health to prosperity to physical environment, this model has an ecological core. One decade later, Northridge et al. did not assume an ecological connection between health and environment, but instead tried to identify variables on different scales connected to health, for example the individual or population scale [17]. In their scheme, health and well-being are also interrelated.

Galea et al. put urban health in context with global and national trends as well as local policies [18]. This connection is established with regards to health as an outcome measure only, without a feedback loop or mediating effect modifications. Great emphasis is placed on governance measures, especially on health governance. The urban environment is furthermore divided into a physical and a social environment, but their systematization of the urban influences on health does not differentiate between natural resources and the built environment. For this reason, the interrelation of the variables remains vague.

Barton et al. then contextualized health with lifestyle, social community, local economy, built and natural environment and the global ecosystem [19]. Their separation of the natural and the built environment is refined by the introduction of stressors in "Public Health Ecology" by Coutts [20]. In this model, ecosystem services are explicitly linked to urban health. Consequently, health outcomes are the target variables of the model, but again without a feedback loop. Because these health outcomes are interpreted as diseases the focus shifts from a salutogenetic to a patogenetic perspective.

Approaching from a medical perspective, Mendis and Banerjee framed the risk for diseases, especially cardio-vascular diseases, mainly in terms of age and social stratification. By this means, differential exposure and vulnerabilities are contextualized by globalization and the economic development of a given city [21]. Honold et al. follow a similar approach in which different health outcomes are more dependent on a lack of resources and multiple stressors. Consequently, they suggest an integrated multiple burden framework [22]. This model places a great emphasis on global trends and policy guidelines, a framework which sets it apart from all other models analyzed.

De Leeuw tries to integrate these different influences on health in her "healthy cities meta-theory". This model aims at policy measures and politically informed interventions on a more regional or city level. Consequently, the interventions proposed mainly focus on health education and health care [23]. This focus is coherent with the actual policy measures emphasized by the healthy city movement, yet this puts less weight on direct environmental stressors, for example. The model developed by Rydin et al. highlights how diseases are influenced by different stressors while remaining connected to cities structures and services [24]. Yet their model provides little systematization or qualification of the effect-modifying interrelations of variables. This is the point we want to improve upon, especially through the conceptual model outlined below.

\subsection{Basic Architecture of the Conceptual Model}

Within the healthy cities movement, health is conceived of as a resource. This understanding goes beyond an absence of illness in medical terms and includes quality of life and general well-being [25]. The conceptual starting point of our model was the Millennium Ecosystem Assessment (MEA) [26] which attempts to model various dimensions of well-being in their dependence upon environmental impacts and ecosystem services. Omitting a critical debate of these dimensions, we define health-related urban well-being (UrbWellth) as the well-being of an urban population. UrbWellth includes domains that are related to individual physical (objective health status), mental (subjective health status) and emotional (affective well-being) aspects of health, to the natural (e.g., climate) and urban specific environment (e.g., public parks) as well as to the political system (e.g., urban governance), social functioning (e.g., neighborhood) and social context (e.g., social position) in which people live [27]. 
This definition goes beyond the MEA approach in at least two respects. First, single and multiple stressors of health have to be identified because of the broad range of individual exposures. That also means that selection criteria for environmental impact factors are derived from possible health impacts on individuals and populations. This increases the complexity of our approach in comparison to earlier models, due to the inclusion of potential stressors deriving from the urban environment as well as the assessment of vulnerability of the urban population on the scale of individuals, groups or quarters and as a whole. Only this way, we argue, can an integration of evidence deriving from natural science, urban research and medical science be fruitful [28]. This interdisciplinary conceptualization offers an interface between urban health research, the vulnerability debate especially within the Intergovernmental Panel on Climate Change (IPCC), and approaches to urban transition. Furthermore, it is outlined not only as a heuristic model to improve our understanding, but also as a basis for a quantitative model to guide monitoring of urban development and scenario building.

In the basic outline of our conceptual model, we assume a separation between citizens and environment, similar to Hancock's approach [13]. Even though the existing models mostly lack an explicit reference to the concepts of human-environment systems, they all address issues of human-environmental relations in one way or another (see Section 1). This binary separation is our first step towards a detailed understanding of the city's internal relations.

In order to establish the basis for a more thorough systematization, we subdivided this binary view into four sectors: individual and society for the citizens, morphology and stressors for the urban environment. This refinement connects our model to Coutt's approach [20], whereby urban morphology encompasses the provision of services, which can be assessed in the sense of an urban ecosystem [29,30]. We also draw here on the approach of Evans and Stoddart [16] for the basic relations between the sectors (Figure 1). Additionally, we agree with their decision not to distinguish between the natural and the built environment, and to discuss the physical environment as a whole (see Morphology). This is especially important in order to avoid natural deterministic errors.

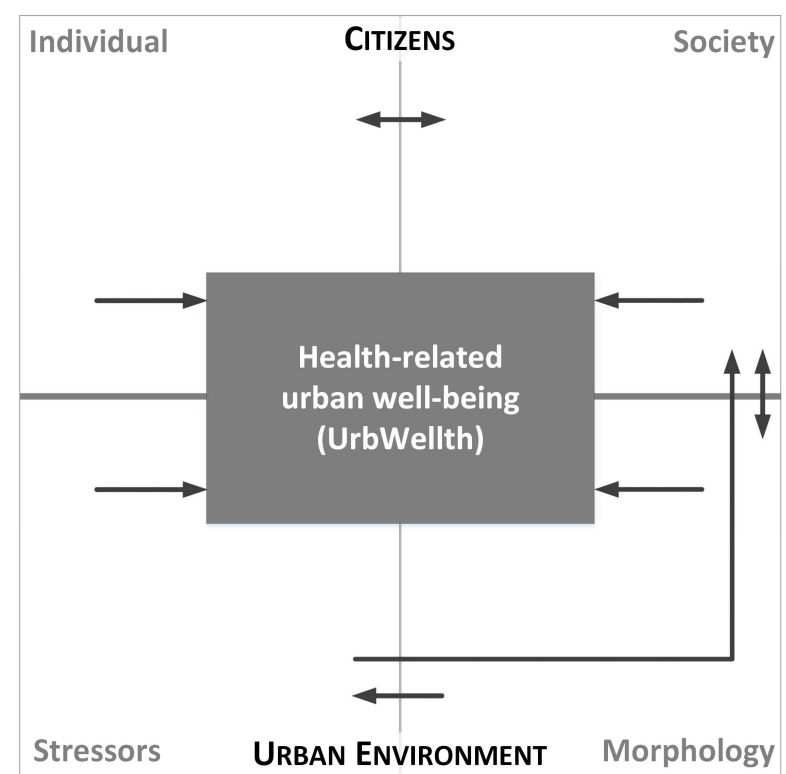

Figure 1. Sectors and interrelations of human-environmental influences on health-related urban well-being (UrbWellth). Arrows indicate influences and interrelations on an aggregated level.

Not all sectors are interrelated. The individual and society sectors influence each other, and so do society and morphology, but there is only a one-way connection between morphology and environmental stressors and between environmental stressors and society. In addition, there is no direct feedback from environmental stressors to the individual sector, a major difference between our 
model and those described above: while some models include a direct feedback, our model mediates the impact of citizens on the environmental stressors by way of morphology, and a potential change in the individual sector due to environmental stressors is mediated by society (while environmental stressors, of course, impact individual health).

This systematization might be best explained by the example of housing. Thomson and Thomas have shown that "despite the lack of clear health impacts within the timescale of existing evaluations, reported impacts on socio-economic determinants of health point to the potential for longer term impacts on health following housing improvement" [31] More specific, Krieger and Higgins found that housing "can influence both physical and mental health, including asthma and other respiratory conditions, injuries, psychological distress, and child development". Still, research on housing and health has primarily focused on the physical aspects of housing, like building conditions [32], while social drivers may have remained undiscovered. In our conceptual model, we separated "built structure" and "household" (see Figure 3 below) to describe and evaluate the quality of the buildings apart from their usage. Ultimately, the influences of "housing" on health depend on a third variable: the exposure to environmental stressors, which cannot be analyzed as ignorant of the social stratification [33].

This conclusion arises from the general assumptions of an interdisciplinary political ecology framework, focusing on environmental changes and conflicts. In this approach, it is generally assumed that, on the one hand, environmental changes result from historical and contemporary political, economic and societal processes which affect nature at different scales [34]; on the other hand, environmental conflicts result from the distribution of and access to resources, rather than simply resource scarcity, for example [35]. Consequently, when focusing on environmental challenges, these do not directly interact with the individual sector, but need "to be related to state policies, interstate relations and global capitalism" [35].

As stated above, the conception of public health needs to be accompanied by an understanding of the vertical stratification [36,37] of city societies and its implications for urban health. Especially useful in this regard is the concept of environmental justice (EJ), which is based on observed correlations of social background and the unequal distribution of environmental stressors, and is related to the basic assumptions of political ecology. While debates on EJ can mainly be traced back to the United States in the late 1970s and early 1980s [38], the established view today is that EJ and public health are related [39-42]. Ideas of EJ are of course related to a much broader debate on the notions of justice: ecological equality of chances, the distribution of access to the basic needs of humanity in a healthy environment, and the right to participate in decisions regarding the protection and transformation of the environment [43-45]. De Leeuw et al. refer to similar qualities in their claim that health equity shall be "the fundamental value guiding healthy cities' policies and programs" [46]. This framing relates a right to health and health equity to the universal human rights addressed by the International Covenant on Economic, Social and Cultural Rights (ICESCR) [47,48]. Our conceptual model helps to identify areas of intervention to address these qualities and values (see Section 2.3).

The effect of any sector on UrbWellth depends on the characteristics of the other sectors. To systemize this effect-modifying influence, we employ a filter based on the concept of vulnerability. This concept also relates to ideas of the human-environment system [49]. A term originally used in work on hazard and risk, vulnerability has been more frequently employed in the field of climate change in the last decades [50,51]. Effect modification through a vulnerability filter is another major difference between our model and other available approaches.

The meaning of vulnerability is too broad in the absence of a supplementary description, and each definition of vulnerability should depend on a certain vulnerable situation [52,53]. The Intergovernmental Panel for Climate Change (IPCC) defined vulnerability (with regard to climate change) as "the degree to which a system is susceptible to, or unable to cope with, adverse effects of climate change [ ... ]. Vulnerability is a function of the [...] climate variation to which a system is exposed, its sensitivity, and its adaptive capacity" [54]. This definition structures vulnerability into 
three elements: exposure, sensitivity and adaptive capacity [55]. Exposure is defined by the IPCC as "the nature and degree to which a system is exposed" [54]. In this sense it acts as an intermediary between the system and the external force. Meanwhile sensitivity is described as the "degree to which a system is affected, either adversely or beneficially" [54]. Sensitivity is also known as social vulnerability and is commonly used in the social sciences [53,56].

Adaptive capacity is "the ability of a system to adjust to [ ... ] potential damages, to take advantage of opportunities or to cope with the consequences" [54]. It absorbs the external influence and mitigates the negative effects. At the same time, it is influenced by a number of variables, including income and poverty, health and education, state support and decision-making, economic opportunities and social cohesion, credit and insurance [57].

We use this understanding of vulnerability to integrate a vulnerability filter layer into our model that modifies the effects of the human-environmental system on UrbWellth (Figure 2). This filter includes so-called transfer functions derived from exposure, sensitivity and adaptive capacity. Consequently stressors such as air pollution do not directly lead to a reduction in UrbWellth. For example, with regards to exposure, urban dwellers are only exposed to air pollutants (with their negative effects on health) when they are outside. Hence, office workers might not be affected while commuters could adapt to bad air quality conditions by taking their car instead of their bike. Here, also the sensitivity of people to air pollutants (e.g., genetic predisposition, general fitness, etc.) has an impact on the final health outcome.

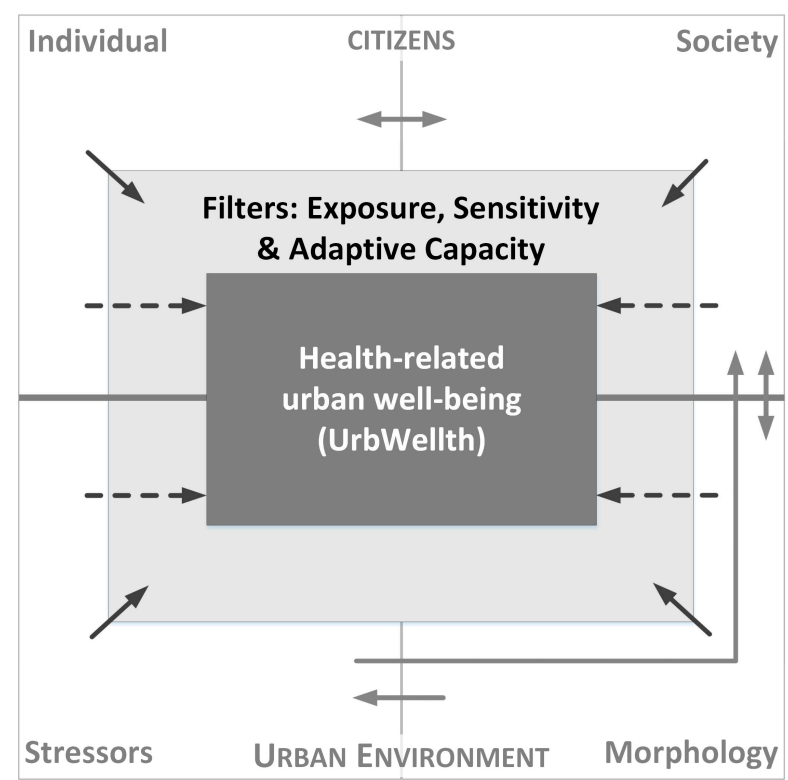

Figure 2. Generalized version of the conceptual model. The three vulnerability filters are joined to one filter layer to simplify the visualization.

Adaptive capacity and sensitivity depend on the variables of all sectors. Exposure depends on society, morphology and stressors only (all dependencies indicated by solid black arrows in Figure 2). With regard to the effect modification of the influence variables, we argue that adaptive capacity and sensitivity affect the health influences of society and stressors, while exposure affects the health influences of morphology and stressors (all modification symbolized by dashed arrows). This obviously extends beyond exposure-only approaches, such as the one used by the World Health Organization to calculate disease-adjusted life years [58,59], for example, arriving at a vulnerability assessment for urban health. 


\subsection{Variables and Interrelations in the Conceptual Model}

As will be supported by the review section on relations below (Section 3), health-related behavior and influences are dependent on four main sectors: individual characteristics, the urban society, the city's morphology and environmental stressors. Our conceptual model systematizes these findings and gives an overview of those variables which are most important for our target value, UrbWellth. This target value is placed in the center while the influencing variables are arranged around it, each within its most closely corresponding sector (Figure 3).

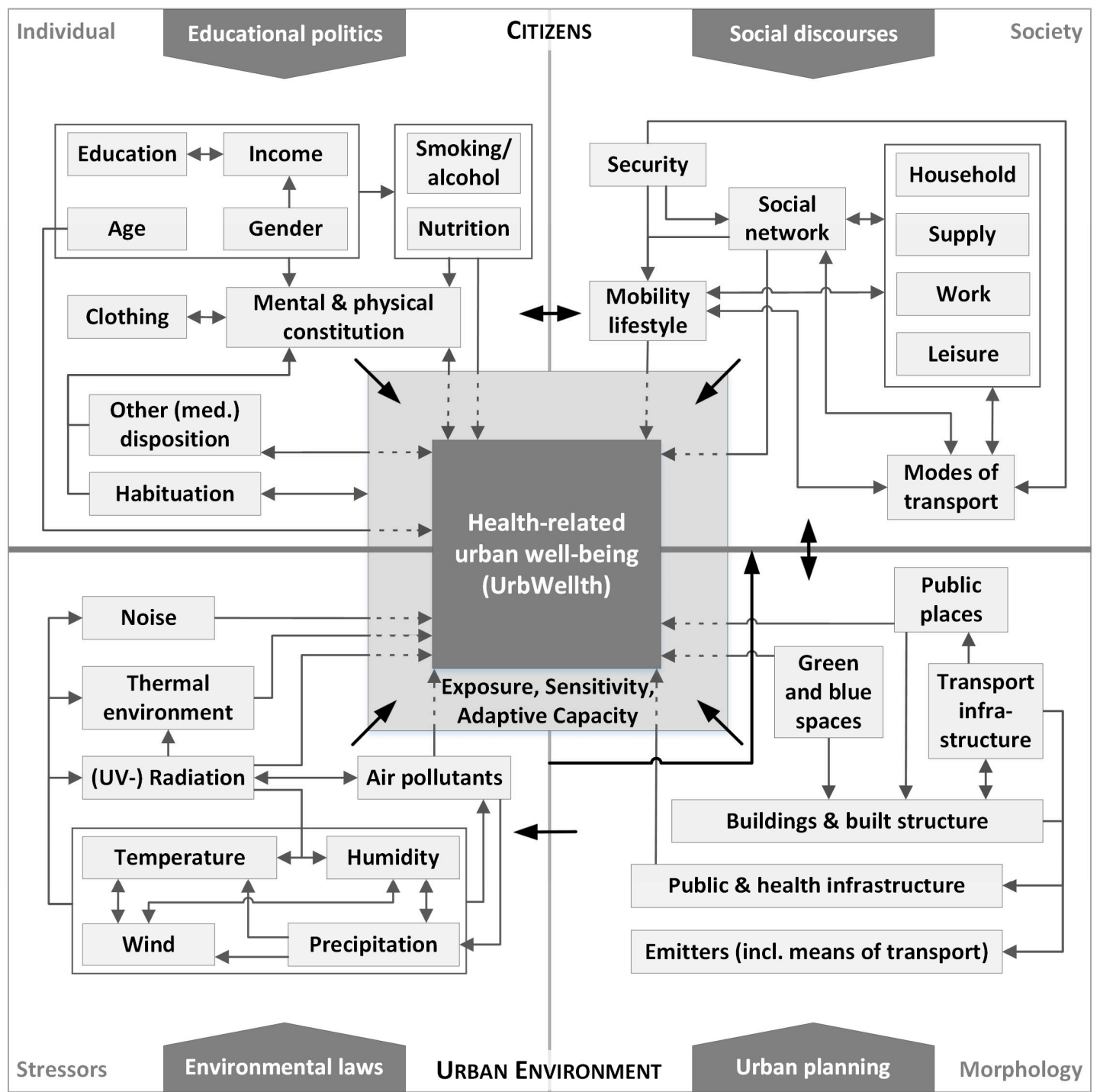

Figure 3. Conceptual model of health-related urban well-being (UrbWellth). Boxes are used to reduce the number of arrows. Because of the complexity of the relations among the determinants of UrbWellth, our framework simplifies some of the potential relations. For more details see text.

The black arrows indicate relations between whole sectors (as in Figure 1) and the filter layer (as in Figure 2). They are thus aggregated relations of a set of variables and/or the filters. The thin gray arrows indicate (inter)relations between the variables, some bidirectional (details are given in Section 3). The four gray block-arrows indicate areas of intervention. Interventions are possible via educational politics (kindergartens, schools, social media, etc.) that seek to instill and encourage healthy or more conscious behavior on both the individual and social levels. In the second sector, social discourses can contribute to healthier lifestyles that may also lead to a reduction of emissions. This in turn will 
ensure lower levels of environmental stressors [60]. This reduction can additionally be supported by, for example, planning a city with sufficient public transport infrastructure [61]. Furthermore, the development of a healthy city is supported by environmental laws [62]. Although environmental stressors cannot be directly changed, knowledge of stressors' effects on health heavily influences social discourses and consequently legislation which may eventually bring about a change in morphology.

The first sector (Individual) gives an overview of the most relevant variables from a medical perspective and their effect on urban health (see Section 3.2). At the same time, it encompasses the most important socioeconomic and -demographic factors used in socio-spatial geography approaches [63-65]. This includes physical and mental constitution, born and acquired dispositions, and, with an emphasis on urban health, a special focus on other medical dispositions (e.g., other diseases).

Habituation [66], also included in this sector, introduces the concept of time: the human body adjusts to the exposure to certain stressors over time. Therefore, habituation is the result of an ongoing adaption. On the one hand, with respect to the thermal environment, the adjustment can be both seasonal, e.g., changes in the comfort temperature between seasons [67,68], and long-term, e.g., adjustment of the basal metabolic rate of people living in different climate regions [69]. On the other hand, noise annoyance is significantly and positively correlated with confounding variables like the length of residence or the years of employment [70].

The individual variables interrelate with the whole second sector (Society). This sector covers variables that refer to concepts of social grouping in geography and social sciences $[65,71,72]$ while also depicting confounding behavioral variables from a medical perspective. Security plays an important role in this sector as it influences several other variables [24,26], such as social activities and interactions. These affect the usage of the city's built environment as well as the sensitivity and adaptive capacity of social groups or individuals [5] (see Section 3.3 for details).

The third sector (Morphology) unites infrastructural variables of the city, including means of transportation. This mobile and immobile built-up city environment serves as an enabling and constraining infrastructure [73], with impacts on human behavior and environmental stressors (details in Section 3.3) [74,75]. The latter constitute the fourth sector (Stressors), encompassing the stressors, modified by the city environment (see Section 3.1 for details on both sectors of the urban environment).

So grouped, our selection of variables and interrelations portrays the major environmental influences on human health and behavior from a geographical, medical and meteorological perspective. This systematization helps to understand the interdependency between different groups of influence variables (e.g., the effects of traffic on traffic infrastructure and vice versa) and the basic relations in cities with respect to urban health.

\section{Health-Related Relations}

\subsection{Urban Impacts on Environmental Variables}

In urban areas, water, thermal and radiation budgets as well as the wind field and the air composition differ from those of rural areas [76] due to the replacement of natural surfaces by artificial surfaces and vertical structures as well as anthropogenic emissions of heat and trace gases. This leads to well-known urban effects such as the urban heat island [77-79], urban impacts on precipitation [80-82] and urban air pollution [83]. In urban areas and metropolitan regions in Europe, air pollution is mainly caused by traffic, with a high share of heavy commercial vehicles [84]. In addition to road traffic, aviation and industry [85] are important sources of air pollutants and noise in cities [86,87].

The dispersion of both air pollutants and noise are mainly influenced by the meteorological conditions and the means of transport [88-90]. For noise propagation Fischer and Ziemann have shown that the structure of the nocturnal urban boundary layer leads to an increase in noise pollution for the city population [91], compared to rural areas. Consequently, meteorological conditions in urban 
areas include the urban morphology effects [61,92,93]. For example, green space can lead to a reduction of noise [94,95] and a reduction in thermal stresses [96,97].

\subsection{Impacts on UrbWellth}

Air pollution and noise pose a threat to major sections of city societies: " $54 \%$ of Germans feel disturbed or harassed by traffic noise" [98]. At the same time, noise has a major effect on urban health: "At least one million healthy life years are lost every year because of traffic-related noise in the western part of Europe" [86]. Nevertheless, it is still an open question as to whether the exposure to air pollutants or the exposure to noise violates principles of environmental justice (Section 4) [99].

Many studies have investigated the relationship between road traffic noise, aircraft noise and different cardiovascular health outcomes [100,101]. Jarup et al. for instance showed significant associations between hypertension and people living close to one of the six major European airports [102]. An additional increase for hypertension could be seen for road traffic noise in the highest exposure category ( $>65 \mathrm{~dB}$ ) [102]. Environmental noise is also considered to be associated with respiratory diseases such as asthma, chronic obstructive pulmonary disease (COPD) [103,104], or mental health symptoms such as depression and anxiety $[105,106]$.

Multiple exposures to particulate matter $\left(\mathrm{PM}_{2.5}\right.$ and $\left.\mathrm{PM}_{10}\right)$, nitrogen dioxide $\left(\mathrm{NO}_{2}\right)$, and elementary carbon, all higher in cities than in rural areas, have been associated with cardiovascular and respiratory disease morbidity and mortality [107] and a decrease in overall well-being [108]. In a multi-city study conducted in Italy, an increase of $\mathrm{PM}_{10}$ resulted in an increase in respiratory mortality at a lag of 0-3 days. This effect was higher in summer [109]. Other studies investigated chronic and long-term exposure of air pollution and found higher risk for all causes and cardio-respiratory mortality [110-112]. The air quality in cities also depends on biogenic emissions such as pollen or volatile organic compounds (VOCs) emitted by street trees as well as from plants in park areas. Both can cause allergic rhinitis (hay fever) [113] or respiratory diseases such as allergic asthma [114].

Comparatively little is known about the effect of air pollution on depressive symptoms or anxiety [115,116]. On the other hand, urban green and blue areas are known to have a positive effect on mental health [42]. In order to develop an appropriate model, it is, therefore, necessary to consider mental aspects, including not only mental illnesses but also subjective evaluations and perceptions of the city and its stressors. Subjective well-being (SWB) is as important to our conception of UrbWellth as are measures of objective well-being. A person with high SWB has high levels of life satisfaction and positive affect and low levels of negative affect compared to the average population [117]. Accordingly, in reference to Diener's influential tri-part model, SWB relates on high life satisfaction, high positive feelings, and low negative feelings [118]. Newman et al. added "detachment-recovery" to the main psychological mechanisms that promote leisure SWB-autonomy, mastery, meaning, and affiliation - to strengthen the everyday domain of leisure, as leisure activities enhance subjective and overall well-being [119]. According to our model, leisure activities that fulfill multiple psychological needs, such as playing soccer at a club or with friends, not only promote SWB and affect mental constitution, but also influence physical constitution which may additionally affect objective health status positively.

To assess the consequences of thermal conditions for health, both human-biometeorological and epidemiological techniques are used. Human-biometeorological studies typically use thermal indices to calculate the impact of the thermal environment on humans $[120,121]$. These indices are increasingly based on human thermo-physiological models [122]. Studies assess the amount of thermal strain or thermal stress in streets, considering specific orientations and aspect ratios $[123,124]$ and proximity to vegetation $[125,126]$ or lakes [127]. In contrast to thermal comfort studies, epidemiological studies do not deal with comfort but statistically link excess morbidity and mortality to temperature. These studies found for numerous cities that mortality increases during periods of extreme heat stress, as well as during periods of cold stress [128-130]. Often several stressors co-occur, e.g., air pollution (ozone $\mathrm{O}_{3}$, summer smog) exacerbated by heat stress [131,132]. 
Besides environmental stressors, co-factors describing genetic predisposition or socio-demographic and socioeconomic background such as gender, age, educational and occupational background or income have to be considered and taken into account as effect-modifying variables. Additionally, behavioral variables such as smoking status, alcohol consumption or physical activity, and variables relating to daily routines, are known to have a major influence on the occurrence of different health outcomes $[100,133,134]$. Finally, access to healthcare and social support play a role in specific health outcomes and should generally be considered in studies as well $[18,135,136]$.

\subsection{Influences on Health-Related Behavior and Society}

Humans influence environmental stressors by way of their lifestyles (e.g., auto exhaust, industry) and by means of city design (e.g., the presence or absence of parks). In turn, environmental stressors also influence lifestyle, particularly outdoor activities and transport modes.

Meteorological conditions explain a significant proportion of the usage of public places, especially parks [137], the engagement in outdoor activities, such as walking [138] and cycling [139], the amount of television viewing [140], or other indoor sedentary activities [141]. The most important determining meteorological variable is air temperature, positively related to outdoor activity $(+)$, sunshine $(+)$ and wind (-) [142-145]. In addition to the impact of thermal variables, precipitation was found to hinder physical activity of all ages $[139,146,147]$. For physical activity and open-air transport, optimal meteorological conditions (warm and dry) exist [139]. In temperate climates, people were observed to be less active in winter than in summer, which may be caused by both shorter periods of daylight and colder conditions $[147,148]$.

People also reduce their outdoor activities and use sheltered transport modes in response to air pollution $[149,150]$. However, not the measured air pollution concentration but the perceived air pollution level leads to a behavioral adjustment [151]. Personal characteristics [152,153], habituation and health problems encountered during previous air pollution events $[149,150]$ were found to impact the perception of air pollution and the resulting behavioral adjustment.

In addition to this natural-sciences perspective, city planning theories provide a view of social behavior from a different perspective. It is the built environment of cities and their infrastructural invitations that mediate constraints and (physical) activities [154]. With a shift in focus from exposition to effects on adaptive capacity, Gehl's approach of an integrated city [73] evaluates physical activities socially. The main thesis is that a city should increase optional and social activities to positively affect the health of urban citizens [42,73]. To achieve this goal, Gehl emphasizes a high quality of public space and the rediscovery of the human scale in urban planning [155]. This approach is closely linked to a change in the modes of (public) transport, induced by policy interventions in the built city environment [156-159]. These mainly impact UrbWellth in two ways: Firstly, an increased share of people using public transport or cycling/walking as modes of transport entails an increase in physical activities (Sector Society in Figure 3) with a positive effect on health outcomes (Section 3.1). Secondly, the reduction of environmental stressors (Sector Stressors in Figure 3) accompanied by this change of transport positively affects UrbWellth [87].

\section{Discussion and Outlook}

Overall, the introduced conceptual model differs from existing approaches mainly through the introduction of the vulnerability filters and the prominent integration of environmental stressors. This enabled us to group the relevant urban influence variables into four major groups and to qualify their relations. It is in the filter layers of vulnerability that the positive and negative effects and variables are put into relation.

The studies reviewed in this paper all vary in scope and scale. Consequently, neither our whole conceptual model nor the four different sectors necessarily imply one scale: the conceptual model is applicable on different scales, spatial and temporal. As presented in Section 3.2, for example, the highest increase in respiratory mortality can be found on the day, or within three days, of an 
air pollution event, while the impact of road traffic noise on cardiovascular diseases is only evident after several years of exposure. A temporal integration might thus be necessary for some variables in implementing this model. This is similarly true on the spatial scale, since some data, especially on health effects, are only available on a district level while environmental stressors, e.g., air pollution, heat or noise, are heterogeneously distributed within a district. Here upscaling of environmental data or a downscaling of health data will be needed to ensure spatial conformity.

The cultural, economic and environmental scope of the conceptual model is heavily dependent on the city as a focus. As we currently develop a multi-sectoral model for Hamburg on the basis of this conceptual model, our considerations are undoubtedly biased towards cities of the global north. On the other hand, we contend that our conceptual model itself is applicable to cities worldwide and describes widely relevant urban variables. For example, public infrastructure such as sanitation is taken for granted in Hamburg, but the quality and maintenance of a sewage system can easily act as a crucial variable in raising the health status of an urban society with relatively poor sanitation, especially in informal settlements.

Positive or negative effects on health are the outcome of complex interactions in the urban system [160]. Still, current studies on the environmental burden of disease (EBD) do not take into account combinations or interactions of different environmental influences. As a result, diseases and premature deaths are only explained in mono-causal ways [161,162]. Our model, however, conceptualizes not only the complexity but also the interdependency of the variables with a focus on UrbWellth. This is a first step to understanding how different variables are (inter)dependent.

For example, it can be deduced from the examples and evidence from the literature that a healthy city should on the one hand promote the activities outside (for example through appropriate infrastructure for biking and walking), but on the other hand this must be linked to clean air. Here, the question is whether regular cycling (to work or leisure activities) alongside a busy road can possibly offset the positive effects of physical activity through exposure to noise and particulate matter. We will therefore refrain at this point to normative demands that have to be prioritized and hierarchized first.

The conceptual model can serve as a design outline for a future quantitative modeling process. In addition, existing models (e.g., atmospheric models, transport models) can be integrated into the sectors of the multi-sectoral model. By coupling multiple models of different sectors, a complex integrated model can be developed. As a first step, atmospheric numerical models such as MITRAS [163] will be used to simulate meteorological variables leading to heat stress, while taking into account the urban morphology. Our vulnerability assessment relates to natural and social sciences as well as to politics, city planning and health-care programs [164]. In addition, only the combination of all four sectors enables us not only to understand the impacts of different variables on health but also to develop effective interventions.

Acknowledgments: This contribution is based on the work of the research project "Cities in Change-Development of a multi-sectoral urban-development impact model (UrbMod)", a joint project of Universität Hamburg, Hamburg University of Technology, University Medical Center Hamburg-Eppendorf, Institute of Coastal Research at Helmholtz Center Geesthacht, Max-Planck-Institute for Meteorology, and Hafen-City University, funded by the State of Hamburg. Part of this work is supported through the Cluster of Excellence "Integrated Climate System Analysis and Prediction" (CliSAP) (EXC177), Universität Hamburg, funded through the German Science Foundation (DFG).

Author Contributions: The conceptual model is based on comprehensive discussions among all authors. The written manuscript includes contributions from all authors and was edited by all authors. Jürgen Oßenbrügge and Malte von Szombathely were responsible for Section 1. Malte von Szombathely was responsible for Section 2; work of Giedrius Kaveckis and Thomas Bürk is included here especially. Jana Fischereit and Myriam Albrecht were responsible for Section 3.1. Anne Caroline Krefis and Jana Fischereit were responsible for Section 3.2. Jana Fischereit, Myriam Albrecht and Malte von Szombathely were responsible for Section 3.3. Peter Hoffmann and Malte von Szombathely were responsible for Section 4.

Conflicts of Interest: The authors declare no conflict of interest. The founding sponsors had no role in the design of the study; in the collection, analyses, or interpretation of data; in the writing of the manuscript, and in the decision to publish the results. 


\section{References}

1. UN Habitat. The State of the World's Cities 2012: Prosperity of Cities; Routledge: London, UK, 2013.

2. UN DESA. World Urbanization Prospects. The 2014 Revision: Highlights; United Nations: New York, NY, USA, 2014.

3. Harlan, S.; Brazel, A.; Prashad, L.; Stefanov, W.; Larsen, L. Neighborhood microclimates and vulnerability to heat stress. Soc. Sci. Med. 2006, 63, 2847-2863. [CrossRef] [PubMed]

4. Vlahov, D.; Freudenberg, N.; Proietti, F.; Ompad, D.; Quinn, A.; Nandi, V.; Galea, S. Urban as a determinant of health. J. Urban Health 2007, 3, 16-26. [CrossRef] [PubMed]

5. World Health Organization. The World Health Report 1998. Life in the 21st Century: A Vision for All; Report of the Director-General; WHO: Geneva, Switzerland, 1998.

6. World Health Organization. Regional Office for Europe. In Health 2020: A European Policy Framework and Strategy for the 21st Century; WHO: Copenhagen, Denmark, 2013.

7. International Council for Science. Health and Wellbeing in the Changing Urban Environment: A Systems Analysis Approach. An Interdisciplinary Science Plan; International Council for Science: Paris, France, 2011. Available online: http:/ /www.icsu.org/publications/reports-and-reviews/health-and-wellbeing/healthand-wellbeing-in-the-changing-urban-environment (accessed on 20 September 2016).

8. Kenzer, M. Healthy cities: A guide to the literature. Environ. Urban. 1999, 1, 201-220. [CrossRef]

9. World Health Organization. Types of Healthy Settings. Available online: http://www.who.int/healthy_ settings/types/cities/en/ (accessed on 20 September 2016).

10. Bai, X.; Nath, I.; Capon, A.; Hasan, N.; Jaron, D. Health and wellbeing in the changing urban environment. Complex challenges, scientific responses, and the way forward. Curr. Opin. Environ. Sustain 2012, 4, 465-472. [CrossRef]

11. Shanahan, D.F.; Lin, B.B.; Bush, R.; Gaston, K.J.; Dean, J.H.; Barber, E.; Fuller, R.A. Toward improved public health outcomes from urban nature. Am. J. Public Health 2015, 3, 470-477. [CrossRef] [PubMed]

12. Van Kamp, I.; Leidelmeijer, K.; Marsman, G.; de Hollander, A. Urban environmental quality and human well-being. Landsc. Urban Plan 2003, 1-2, 5-18. [CrossRef]

13. Hancock, T. Lalonde and beyond. Looking back at "A New Perspective on the Health of Canadians". Health Promot. Int. 1986, 1, 93-100. [CrossRef]

14. Coutts, C. Green Infrastructure and Public Health; Routledge: Abingdon, UK; New York, NY, USA, 2016.

15. Hancock, T. The mandala of health. A model of the human ecosystem. Fam. Community Health 1985, 3, 1-10.

16. Evans, R.G.; Stoddart, G.L. Producing health, consuming health care. Soc. Sci. Med. 1990, 12, $1347-1363$. [CrossRef]

17. Northridge, M.E.; Sclar, E.D.; Biswas, M.P. Sorting out the connections between the built environment and health: A conceptual framework for navigating pathways and planning healthy cities. J. Urban Health 2003, 4, 556-568. [CrossRef] [PubMed]

18. Galea, S.; Freudenberg, N.; Vlahov, D. Cities and population health. Soc. Sci. Med. 2005, 5, $1017-1033$. [CrossRef] [PubMed]

19. Barton, H.; Grant, M. A health map for the local human habitat. J. R. Soc. Promot. Health 2006, 6, $252-253$. [CrossRef]

20. Coutts, C. Public health ecology. J. Environ. Health 2010, 72, 53-55. [PubMed]

21. Mendis, S.; Banerjee, A. Cardiovascular disease: Equity and social determinants. In Equity, Social Determinants and Public Health Programmes; Blas, E., Kurup, A.S., Eds.; WHO: Geneva, Switzerland, 2010; pp. 32-48.

22. Honold, J.; Beyer, R.; Lakes, T.; van der Meer, E. Multiple environmental burdens and neighborhood-related health of city residents. J. Environ. Psychol. 2012, 4, 305-317. [CrossRef]

23. De Leeuw, E. Evidence for Healthy Cities: Reflections on practice, method and theory. Health Promot. Int. 2009, 24, i19-i36. [CrossRef] [PubMed]

24. Rydin, Y.; Bleahu, A.; Davies, M.; Dávila, J.D.; Friel, S.; de Grandis, G.; Groce, N.; Hallal, P.C.; Hamilton, I.; Howden-Chapman, P.; et al. Shaping cities for health. Complexity and the planning of urban environments in the 21st century. Lancet 2012, 9831, 2079-2108. [CrossRef]

25. Kickbush, I. The move towards a new public health. Promot. Educ. 2007, 14, 9.

26. Millennium Ecosystem Assessment. Ecosystems and Human Well-Being: Synthesis; Island Press: Washington, DC, USA, 2005. 
27. Ballas, D. What makes a 'happy city'? Cities 2013, 32, S39-S50. [CrossRef]

28. Spiro, A.; Bossé, R. Relations between health-related quality of life and well-being: The gerontologist's new clothes? Int. J. Aging Hum. Dev. 2000, 4, 297-318. [CrossRef] [PubMed]

29. Bolund, P.; Hunhammar, S. Ecosystem services in urban areas. Ecol. Econ. 1999, 2, 293-301. [CrossRef]

30. Haase, D.; Larondelle, N.; Andersson, E.; Artmann, M.; Borgstrom, S.; Breuste, J.; Gomez-Baggethun, E.; Gren, A.; Hamstead, Z.; Hansen, R.; et al. A quantitative review of urban ecosystem service assessments: concepts, models, and implementation. Ambio 2014, 4, 413-433. [CrossRef] [PubMed]

31. Thomson, H.; Thomas, S. Developing empirically supported theories of change for housing investment and health. Soc. Sci. Med. 2015, 124, 205-214. [CrossRef] [PubMed]

32. Krieger, J.; Higgins, D.L. Housing and health: Time again for public health action. Am. J. Public Health 2002, 92, 758-768. [CrossRef] [PubMed]

33. Krieger, N. Theories for social epidemiology in the 21st century: An ecosocial perspective. Int. J. Epidemiol. 2001, 30, 668-677. [CrossRef] [PubMed]

34. Bryant, R.L.; Bailey, S. Third World Political Ecology: An Introduction; Routledge: London, UK, 1997.

35. Bryant, R.L. Political ecology: An emerging research agenda in Third-World studies. Political Geogr. 1992, 1, 12-36. [CrossRef]

36. Bourdieu, P. Die Feinen Unterschiede. Kritik Der Gesellschaftlichen Urteilskraft, 5th ed.; Suhrkamp: Frankfurt, Germany, 1992.

37. Grusky, D.B. Theories of Stratification and Inequality. In The Concise Encyclopedia of Sociology; Ritzer, G., Ryan, J.M., Eds.; Wiley-Blackwell: Chichester, UK, 2011; pp. 622-624.

38. Walker, G.; Bulkeley, H. Geographies of environmental justice. Geoforum 2006, 5, 655-659. [CrossRef]

39. Brulle, R.J.; Pellow, D.N. Environmental justice: Human health and environmental inequalities. Annu. Rev. Public Health 2006, 27, 103-124. [CrossRef] [PubMed]

40. Evans, G.W. The built environment and mental health. J. Urban Health 2003, 4, 536-555. [CrossRef] [PubMed]

41. Lee, C. Environmental justice: Building a unified vision of health and the environment. Environ. Health Perspect. 2002, 2, 141-144. [CrossRef]

42. Taylor, W.C.; Floyd, M.F.; Whitt-Glover, M.C.; Brooks, J. Environmental justice: A framework for collaboration between the public health and parks and recreation fields to study disparities in physical activity. J. Phys. Act. Health 2007, 4, S50-S63. [CrossRef] [PubMed]

43. Bolte, G. Umweltgerechtigkeit. In Chancengleichheit bei Umwelt und Gesundheit: Konzepte, Datenlage und Handlungsperspektiven, 1 ed.; Huber: Bern, Switzerland, 2012.

44. Maschewsky, W. Umweltgerechtigkeit, Public Health und Soziale Stadt; Verlag für Akademische Schriften (VAS): Frankfurt (Main), Germany, 2001.

45. Sen, A. The Idea of Justice; Belknap Press of Harvard University Press: Cambridge, MA, USA, 2009.

46. De Leeuw, E.; Tsouros, A.D.; Dyakova, M.; Green, G. Healthy cities. Promoting health and equity-evidence for local policy and practice. In Summary Evaluation of Phase V of the WHO European Healthy Cities Network; WHO Regional Office for Europe: Copenhagen, Denmark, 2014.

47. Backman, G.; Hunt, P.; Khosla, R.; Jaramillo-Strouss, C.; Fikre, B.M.; Rumble, C.; Pevalin, D.; Páez, D.A.; Pineda, M.A.; Frisancho, A.; et al. Health systems and the right to health. An assessment of 194 countries. Lancet 2008, 9655, 2047-2085. [CrossRef]

48. UN. International Covenant on Economic, Social and Cultural Rights 1966. Available online: http://www. ohchr.org/EN/ProfessionalInterest/Pages/CESCR.aspx (accessed on 20 September 2016).

49. Turner, B.L.; Kasperson, R.E.; Matson, P.A.; McCarthy, J.J.; Corell, R.W.; Christensen, L.; Eckley, N.; Kasperson, J.X.; Luers, A.; Martello, M.L.; et al. A framework for vulnerability analysis in sustainability science. Proc. Natl. Acad. Sci. USA 2003, 14, 8074-8079. [CrossRef] [PubMed]

50. Beck, U. Risikogesellschaft. In Auf dem Weg in eine Andere Moderne, 1st ed.; Suhrkamp: Frankfurt, Germany, 1986. (In German)

51. Cutter, S.L. Hazards Vulnerability and Environmental Justice; Earthscan Publications: London, UK, 2006.

52. Füssel, H.-M. Vulnerability in Climate Change Research: A Comprehensive Conceptual Framework. Breslauer, Potsdam Institute for Climate Impact Research \& Stockholm Environment Institute. Working Paper. Available online: https://www.pik-potsdam.de/research/projects/projects-archive/favaia/pubs/ fuessel_2005.pdf (accessed on 20 September 2016).

53. Green, C. The evaluation of vulnerability to flooding. Disaster Prev. Manag. 2004, 4, 323-329. [CrossRef] 
54. Thornes, J.E. IPCC, 2001. Climate change 2001: Impacts, adaptation and vulnerability. Contribution of Working Group II to the Third Assessment Report of the Intergovernmental Panel on Climate Change. Int. J. Climatol. 2002, 10, 1285-1286. [CrossRef]

55. European Environment Agency. Regional Climate Change and Adaptation: The Alps Facing the Challenge of Changing Water Resources; Office for Official Publ. of the Europ. Communities: Luxembourg, 2009. Available online: http://www.riob.org/IMG/pdf/EEA_Report_8-2009_Alps.pdf (accessed on 20 September 2016).

56. Brooks, N. Vulnerability, risk and adaptation: A conceptual framework. Working Paper. 2003. Available online: http: / /www.tyndall.ac.uk/sites/default/files/wp38.pdf (accessed on 20 September 2016).

57. Scheffran, J. The Security Risks of Climate Change: Vulnerabilities, Threats, Conflicts and Strategies. In Coping with Global Environmental Change, Disasters and Security: Threats, Challenges, Vulnerabilities and Risks; Brauch, H.G., Spring, U.O., Mesjasz, C., Grin, J., Kameri-Mbote, P., Chourou, B., Dunay, P., Birkmann, J., Eds.; Springer: Berlin, Germany, 2011; pp. 735-756.

58. Lopez, A.D. Global Burden of Disease and Risk Factors; Oxford University Press: New York, NY, USA; World Bank: Washington, DC, USA, 2006.

59. World Health Organization. Quantification of the Disease Burden Attributable to Environmental Risk Factors; WHO: Geneva, Switzerland, 2015.

60. Lakes, T.; Brückner, M.; Krämer, A. Development of an environmental justice index to determine socio-economic disparities of noise pollution and green space in residential areas in Berlin. J. Environ. Plan. Manag. 2013, 4, 538-556. [CrossRef]

61. Mills, G.; Cleugh, H.; Emmanuel, R.; Endlicher, W.; Erell, E.; McGranahan, G.; Ng, E.; Nickson, A.; Rosenthal, J.; Steemer, K. Climate Information for Improved Planning and Management of Mega Cities (Needs Perspective). Procedia Environ. Sci. 2010, 1, 228-246. [CrossRef]

62. US EPA. EJSCREEN: Environmental Justice Screening and Mapping Tool. Available online: http://www. epa.gov / ejscreen (accessed on 20 September 2016).

63. Gregory, D.; Urry, J. Social Relations and Spatial Structures; Macmillan: New York, NY, USA, 1985.

64. Pohl, T. Entgrenzte Stadt. Räumliche Fragmentierung und Zeitliche Flexibilisierung in der Spätmoderne; Transcript: Bielefeld, Germany, 2009. (In German)

65. Storper, M. Keys to the City. In How Economics, Institutions, Social Interactions, and Politics Shape Development; Princeton University Press: Princeton, NJ, USA, 2013.

66. De Freitas, C.R.; Grigorieva, E.A. The impact of acclimatization on thermophysiological strain for contrasting regional climates. Int. J. Biometeorol. 2014, 10, 2129-2137. [CrossRef] [PubMed]

67. Koppe, C.; Jendritzky, G. Inclusion of short-term adaptation to thermal stresses in a heat load warning procedure. Meteorol. Z. 2005, 2, 271-278. [CrossRef]

68. Lin, T.-P. Thermal perception, adaptation and attendance in a public square in hot and humid regions. Build. Environ. 2009, 10, 2017-2026. [CrossRef]

69. Froehle, A.W. Climate variables as predictors of basal metabolic rate: New equations. Am. J. Hum. Boil. 2008, 5, 510-529. [CrossRef] [PubMed]

70. Jakovljevic, B.; Paunovic, K.; Belojevic, G. Road-traffic noise and factors influencing noise annoyance in an urban population. Environ. Int. 2009, 3, 552-556. [CrossRef] [PubMed]

71. Jürgens, C.; Kasper, B. Alltagsmobilität, Raum und Lebensstile. In StadtLeben-Wohnen, Mobilität und Lebensstil: Neue Perspektiven für Raum- und Verkehrsentwicklung, 1st ed.; Beckmann, K.J., Ed.; VS, Verl. für Sozialwiss: Wiesbaden, Germany, 2006; pp. 125-141. (In German)

72. Oßenbrügge, J.; Pohl, T.; Vogelpohl, A. Entgrenzte Zeitregime und wirtschaftsräumliche Konzentrationen. Z. Wirtsch. 2009, 53, 249-263. [CrossRef]

73. Gehl, J. Leben Zwischen Häusern; Jovis Verlag: Berlin, Germany, 2012. (In German)

74. Hägerstrand, T. The Impact of Transport on the Quality of Life; Lunds Universitets Kulturgeografiska Institution: Lund, Sweden, 1974.

75. Hägerstrand, T. What about people in Regional Science? Pap. Reg. Sci. Assoc. 1970, 1, 6-21. [CrossRef]

76. Oke, T.R. Boundary Layer Climates, 2nd ed.; Routledge: London, UK, 1987.

77. Arnfield, A.J. Two decades of urban climate research: A review of turbulence, exchanges of energy and water, and the urban heat island. Int. J. Climatol. 2003, 1, 1-26. [CrossRef]

78. Bechtel, B.; Schmidt, K. Floristic mapping data as a proxy for the mean Urban heat Island. Clim. Res. 2011, 1, 45-58. [CrossRef] 
79. Hoffmann, P.; Krueger, O.; Schlünzen, K.H. A statistical model for the urban heat island and its application to a climate change scenario. Int. J. Climatol. 2012, 8, 1238-1248. [CrossRef]

80. Han, J.-Y.; Baik, J.-J.; Lee, H. Urban impacts on precipitation. Asia-Pac. J. Atmos. Sci. 2014, 1, 17-30. [CrossRef]

81. Schlünzen, K.H.; Hoffmann, P.; Rosenhagen, G.; Riecke, W. Long-term changes and regional differences in temperature and precipitation in the metropolitan area of Hamburg. Int. J. Climatol. 2010, 8, 1121-1136. [CrossRef]

82. Shepherd, J.M. A Review of Current Investigations of Urban-Induced Rainfall and Recommendations for the Future. Earth Interact. 2005, 12, 1-27. [CrossRef]

83. Moussiopoulos, N. (Ed.) Air Quality in Cities; Springer: Berlin, Germany, 2003; p. 297.

84. Mage, D.; Ozolins, G.; Peterson, P.; Webster, A.; Orthofer, R.; Vandeweerd, V.; Gwynne, M. Urban air pollution in megacities of the world. Atmos. Environ. 1996, 5, 681-686. [CrossRef]

85. Ross, B.M.; Wolde, T. Ten Noise from traffic as a worldwide policy problem. Noise Control Eng. J. $2001,4,159$. [CrossRef]

86. Kheirbek, I.; Ito, K.; Neitzel, R.; Kim, J.; Johnson, S.; Ross, Z.; Eisl, H.; Matte, T. Spatial variation in environmental noise and air pollution in New York City. J. Urban Health 2014, 3, 415-431. [CrossRef] [PubMed]

87. World Health Organization. Burden of Disease from Environmental Noise. Quantification of Healthy Life Years Lost in Europe; World Health Organization: Geneva, Switzerland, 2011.

88. Heimann, D. Schallausbreitung Unter Meteorologischen und Topografischen Gegebenheiten. PhD thesis, Deutsches Zentrum für Luft-und Raumfahrt, Cologne, Germany, 2003.

89. Kohoutek, S. Quantifizierung der Wirkungen des Straßenverkehrs auf Partikel- und Stickoxid-Immissionen. PhD thesis, Technische Universität Darmstadt, Darmstadt, Germany, 2010.

90. Mayer, H. Air pollution in cities. Atmos. Environ. 1999, 24-25, 4029-4037. [CrossRef]

91. Fischer, G.; Ziemann, A. Untersuchung des Einflusses der Variierenden Urbanen Grenzschicht auf die Schallausbreitung. Available online: https://www.researchgate.net/profile/Astrid_Ziemann/ publication/261637274_Untersuchung_des_Einflusses_der_variierenden_urbanen_Grenzschicht_auf_die_ Schallausbreitung/links/02e7e534e4f661c129000000.pdf (accessed on 20 September 2016).

92. Stewart, I.D.; Oke, T.R. Local Climate Zones for Urban Temperature Studies. Bull. Am. Meteorol. Soc. 2012, 12, 1879-1900. [CrossRef]

93. Schlünzen, K.H.; Grawe, D.; Bohnenstengel, S.I.; Schlüter, I.; Koppmann, R. Joint modelling of obstacle induced and mesoscale changes-Current limits and challenges. J. Wind Eng. Ind. Aerodyn. 2011, 99, 217-225. [CrossRef]

94. Yang, W.; Kang, J. Acoustic comfort evaluation in urban open public spaces. Appl. Acoust. 2005, 2, $211-229$. [CrossRef]

95. Yang, W.; Kang, J. Soundscape and Sound Preferences in Urban Squares. A Case Study in Sheffield. J. Urban Des. 2005, 1, 61-80. [CrossRef]

96. Bowler, D.E.; Buyung-Ali, L.; Knight, T.M.; Pullin, A.S. Urban greening to cool towns and cities. A systematic review of the empirical evidence. Landsc. Urban Plan. 2010, 3, 147-155. [CrossRef]

97. Chen, L.; $\mathrm{Ng}$, E. Simulation of the effect of downtown greenery on thermal comfort in subtropical climate using PET index. A case study in Hong Kong. Archit. Sci. Rev. 2013, 4, 297-305. [CrossRef]

98. Umweltbundesamt. Umweltbewusstsein in Deutschland 2014. Ergebnisse Einer Repräsentativen Bevölkerungsumfrage; Umweltbundesamt (UBA): Dessau-Roßlau, Germany, 2015.

99. Gaffron, P. Urban transport, environmental justice and human daily activity patterns. Transp. Policy 2012, 20, 114-127. [CrossRef]

100. Babisch, W.; Wolf, K.; Petz, M.; Heinrich, J.; Cyrys, J.; Peters, A. Associations between traffic noise, particulate air pollution, hypertension, and isolated systolic hypertension in adults: The KORA study. Environ. Health Perspect. 2014, 5, 492-498. [CrossRef] [PubMed]

101. Babisch, W.; Wölke, G.; Heinrich, J.; Straff, W. Road traffic noise and hypertension-accounting for the location of rooms. Environ. Res. 2014, 133, 380-387. [CrossRef] [PubMed]

102. Jarup, L.; Babisch, W.; Houthuijs, D.; Pershagen, G.; Katsouyanni, K.; Cadum, E.; Dudley, M.-L.; Savigny, P.; Seiffert, I.; Swart, W.; et al. Hypertension and exposure to noise near airports: The HYENA study. Environ. Health Perspect. 2008, 3, 329-333. 
103. Duhme, H.; Weiland, S.K.; Keil, U.; Kraemer, B.; Schmid, M.; Stender, M.; Chambless, L. The association between self-reported symptoms of asthma and allergic rhinitis and self-reported traffic density on street of residence in adolescents. Epidemiology 1996, 6, 578-582. [CrossRef]

104. Ising, H.; Lange-Asschenfeldt, H.; Lieber, G.F.; Weinhold, H.; Eilts, M. Respiratory and dermatological diseases in children with long-term exposure to road traffic immissions. Noise Health 2003, 19, 41-50.

105. Hiramatsu, K.; Yamamoto, T.; Taira, K.; Ito, A.; Nakasone, T. A survey on health effects due to aircraft noise on residents living around kadena air base in the ryukyus. J. Sound Vib. 1997, 4, 451-460. [CrossRef]

106. Yoshida, T.; Osada, Y.; Kawaguchi, T.; Hoshiyama, Y.; Yoshida, K.; Yamamoto, K. Effects of road traffic noise on inhabitants of tokyo. J. Sound Vib. 1997, 4, 517-522. [CrossRef]

107. Brunekreef, B.; Holgate, S.T. Air pollution and health. Lancet 2002, 9341, 1233-1242. [CrossRef]

108. Orru, K.; Orru, H.; Maasikmets, M.; Hendrikson, R.; Ainsaar, M. Well-being and environmental quality: Does pollution affect life satisfaction? Qual. Life Res. 2015, 25, 699-705. [CrossRef] [PubMed]

109. Faustini, A.; Stafoggia, M.; Berti, G.; Bisanti, L.; Chiusolo, M.; Cernigliaro, A.; Mallone, S.; Primerano, R.; Scarnato, C.; Simonato, L.; et al. The relationship between ambient particulate matter and respiratory mortality: A multi-city study in Italy. Eur. Respir. J. 2011, 3, 538-547. [CrossRef] [PubMed]

110. Gehring, U.; Heinrich, J.; Krämer, U.; Grote, V.; Hochadel, M.; Sugiri, D.; Kraft, M.; Rauchfuss, K.; Eberwein, H.G.; Wichmann, H.-E. Long-term exposure to ambient air pollution and cardiopulmonary mortality in women. Epidemiology 2006, 5, 545-551. [CrossRef] [PubMed]

111. Naess, O.; Nafstad, P.; Aamodt, G.; Claussen, B.; Rosland, P. Relation between concentration of air pollution and cause-specific mortality: Four-year exposures to nitrogen dioxide and particulate matter pollutants in 470 neighborhoods in Oslo, Norway. Am. J. Epidemiol. 2007, 4, 435-443. [CrossRef] [PubMed]

112. Pope, C.A.; Burnett, R.T.; Thurston, G.D.; Thun, M.J.; Calle, E.E.; Krewski, D.; Godleski, J.J. Cardiovascular mortality and long-term exposure to particulate air pollution: Epidemiological evidence of general pathophysiological pathways of disease. Circulation 2004, 1, 71-77. [CrossRef] [PubMed]

113. Ziello, C.; Sparks, T.H.; Estrella, N.; Belmonte, J.; Bergmann, K.C.; Bucher, E.; Brighetti, M.A.; Damialis, A.; Detandt, M.; Galán, C.; et al. Changes to airborne pollen counts across Europe. PLoS ONE 2012, 4, e34076. [CrossRef] [PubMed]

114. D'Amato, G.; Holgate, S.T.; Pawankar, R.; Ledford, D.K.; Cecchi, L.; Al-Ahmad, M.; Al-Enezi, F.; Al-Muhsen, S.; Ansotegui, I.; Baena-Cagnani, C.E.; et al. Meteorological conditions, climate change, new emerging factors, and asthma and related allergic disorders. A statement of the World Allergy Organization. World Allergy Organ. J. 2015, 1, 407.

115. Lim, Y.-H.; Kim, H.; Kim, J.H.; Bae, S.; Park, H.Y.; Hong, Y.-C. Air pollution and symptoms of depression in elderly adults. Environ. Health Perspect. 2012, 120, 1023-1028. [CrossRef] [PubMed]

116. Tzivian, L.; Winkler, A.; Dlugaj, M.; Schikowski, T.; Vossoughi, M.; Fuks, K.; Hoffmann, B. Effect of long-term outdoor air pollution and noise on cognitive and psychological functions in adults. Int. J. Hyg. Environ. Health 2015, 218, 1-11. [CrossRef] [PubMed]

117. Diener, E.; Oishi, S.; Lucas, R.E. Personality, culture, and subjective well-being: Emotional and Cognitive Evaluations of Life. Annu. Rev. Psychol. 2003, 54, 403-425. [CrossRef] [PubMed]

118. Diener, E. Subjective well-being. Psychol. Bull. 1984, 95, 542-575. [CrossRef] [PubMed]

119. Newman, D.B.; Tay, L.; Diener, E. Leisure and Subjective Well-Being: A Model of Psychological Mechanisms as Mediating Factors. J. Happiness Stud. 2014, 15, 555-578. [CrossRef]

120. Błażejczyk, K.; Epstein, Y.; Jendritzky, G.; Staiger, H.; Tinz, B. Comparison of UTCI to selected thermal indices. Int. J. Biometeorol. 2012, 3, 515-535. [CrossRef] [PubMed]

121. De Freitas, C.R.; Grigorieva, E.A. A comprehensive catalogue and classification of human thermal climate indices. Int. J. Biometeorol. 2015, 1, 109-120. [CrossRef] [PubMed]

122. McGregor, G. Human biometeorology. Prog. Phys. Geogr. 2011, 1, 93-109. [CrossRef]

123. Ali-Toudert, F.; Mayer, H. Numerical study on the effects of aspect ratio and orientation of an urban street canyon on outdoor thermal comfort in hot and dry climate. Build. Environ. 2006, 2, 94-108. [CrossRef]

124. Holst, J.; Mayer, H. Impacts of street design parameters on human-biometeorological variables. Meteorol. Z. 2011, 5, 541-552. [CrossRef]

125. Ketterer, C.; Matzarakis, A. Human-biometeorological assessment of heat stress reduction by replanning measures in Stuttgart, Germany. Landsc. Urban Plan. 2014, 122, 78-88. [CrossRef] 
126. Thorsson, S.; Rocklöv, J.; Konarska, J.; Lindberg, F.; Holmer, B.; Dousset, B.; Rayner, D. Mean radiant temperature-A predictor of heat related mortality. Urban Clim. 2014, 10, 332-345. [CrossRef]

127. Theeuwes, N.E.; Solcerová, A.; Steeneveld, G.J. Modeling the influence of open water surfaces on the summertime temperature and thermal comfort in the city. J. Geophys. Res. Atmos. 2013, 16, 8881-8896. [CrossRef]

128. McMichael, A.J.; Wilkinson, P.; Kovats, R.S.; Pattenden, S.; Hajat, S.; Armstrong, B.; Vajanapoom, N.; Niciu, E.M.; Mahomed, H.; Kingkeow, C.; et al. International study of temperature, heat and urban mortality: The 'ISOTHURM' project. Int. J. Epidemiol. 2008, 5, 1121-1131. [CrossRef] [PubMed]

129. Wu, W.; Xiao, Y.; Li, G.; Zeng, W.; Lin, H.; Rutherford, S.; Xu, Y.; Luo, Y.; Xu, X.; Chu, C.; et al. Temperature-mortality relationship in four subtropical Chinese cities: A time-series study using a distributed lag non-linear model. Sci. Total Environ. 2013, 449, 355-362. [CrossRef] [PubMed]

130. Ye, X.; Wolff, R.; Yu, W.; Vaneckova, P.; Pan, X.; Tong, S. Ambient temperature and morbidity: A review of epidemiological evidence. Environ. Health Perspect. 2012, 1, 19-28. [CrossRef] [PubMed]

131. Analitis, A.; Becker, P.; Biggeri, A.; zak Bouchama, A.; De'Donato, F.; D'Ippoliti, D.; Hajat, S.; Hales, S.; Katsouyanni, K.; Kirchmayer, U.; et al. Improving Public Health Responses to Extreme Weather/heat-Waves-EuroHEAT; World Health Organization: Copenhagen, Denmark, 2009.

132. Burkart, K.; Canário, P.; Breitner, S.; Schneider, A.; Scherber, K.; Andrade, H.; Alcoforado, M.J.; Endlicher, W. Interactive short-term effects of equivalent temperature and air pollution on human mortality in Berlin and Lisbon. Environ. Pollut. 2013, 183, 54-63. [CrossRef] [PubMed]

133. Babisch, W.; Swart, W.; Houthuijs, D.; Selander, J.; Bluhm, G.; Pershagen, G.; Dimakopoulou, K.; Haralabidis, A.S.; Katsouyanni, K.; Davou, E.; et al. Exposure modifiers of the relationships of transportation noise with high blood pressure and noise annoyance. J. Acoust. Soc. Am. 2012, 6, 3788-3808. [CrossRef] [PubMed]

134. Bodin, T.; Albin, M.; Ardö, J.; Stroh, E.; Ostergren, P.-O.; Björk, J. Road traffic noise and hypertension: Results from a cross-sectional public health survey in southern Sweden. Environ. Health 2009, 8, 38. [CrossRef] [PubMed]

135. Gusmano, M.K.; Weisz, D.; Rodwin, V.G.; Lang, J.; Qian, M.; Bocquier, A.; Moysan, V.; Verger, P. Disparities in access to health care in three French regions. Health Policy 2014, 1, 31-40. [CrossRef] [PubMed]

136. Sørgaard, K.W.; Sandlund, M.; Heikkilä, J.; Hansson, L.; Vinding, H.R.; Bjarnason, O.; Bengtsson-Tops, A.; Merinder, L.; Nilsson, L.-L.; Middelboe, T. Schizophrenia and contact with health and social services: A Nordic multi-centre study. Nord. J. Psychiatry 2003, 4, 253-261. [CrossRef] [PubMed]

137. Thorsson, S.; Tsuyoshi, H.; Lindberg, F.; Eliasson, I.; Lim, E.-M. Thermal Comfort and Outdoor Activity in Japanese Urban Public Places. Environ. Behav. 2007, 5, 660-684. [CrossRef]

138. De Montigny, L.; Ling, R.; Zacharias, J. The Effects of Weather and Walking Rates in Nine Cities. Environ. Behav. 2012, 6, 821-840. [CrossRef]

139. Böcker, L.; Thorsson, S. Integrated weather effects on cycling shares, frequencies, and durations in Rotterdam, the Netherlands. Weather Clim. Soc. 2014, 6, 468-481. [CrossRef]

140. Eisinga, R.; Franses, P.; Vergeer, M. Weather conditions and daily television use in the Netherlands, 1996-2005. Int. J. Biometeorol. 2011, 4, 555-564. [CrossRef] [PubMed]

141. Spinney, J.E.L; Millward, H. Weather impacts on leisure activities in Halifax, Nova Scotia. Int. J. Biometeorol. 2010, 2, 133-145. [CrossRef] [PubMed]

142. Eliasson, I.; Knez, I.; Westerberg, U.; Thorsson, S.; Lindberg, F. Climate and behaviour in a Nordic city. Landsc. Urban Plan 2007, 1-2, 72-84. [CrossRef]

143. Knez, I.; Thorsson, S.; Eliasson, I.; Lindberg, F. Psychological mechanisms in outdoor place and weather assessment: Towards a conceptual model. Int. J. Biometeorol. 2009, 1, 101-111. [CrossRef] [PubMed]

144. Thorsson, S.; Lindqvist, M.; Lindqvist, S. Thermal bioclimatic conditions and patterns of behaviour in an urban park in Göteborg, Sweden. Int. J. Biometeorol. 2004, 48, 149-156. [CrossRef] [PubMed]

145. Zacharias, J.; Stathopoulos, T.; Wu, H. Microclimate and Downtown Open Space Activity. Environ. Behav. 2001, 2, 296-315. [CrossRef]

146. Chan, C.B.; Ryan, D.A. Assessing the Effects of Weather Conditions on Physical Activity Participation Using Objective Measures. Int. J. Environ. Res. Public Health 2009, 10, 2639-2654. [CrossRef] [PubMed]

147. Togo, F.; Watanabe, E.; Park, H.; Shephard, J.R.; Aoyagi, Y. Meteorology and the physical activity of the elderly: The Nakanojo Study. Int. J. Biometeorol. 2005, 2, 83-89. [CrossRef] [PubMed] 
148. Sumukadas, D.; Witham, M.; Struthers, A.; McMurdo, M. Day length and weather conditions profoundly affect physical activity levels in older functionally impaired people. J. Epidemiol. Community Health 2009, 4, 305-309. [CrossRef] [PubMed]

149. Bresnahan, B.W.; Dickie, M.; Gerking, S. Averting Behavior and Urban Air Pollution. Land Econ. 1997, 3 , 340-357. [CrossRef]

150. Skov, T.; Cordtz, T.; Jensen, L.K.; Saugman, P.; Schmidt, K.; Theilade, P. Modifications of health behaviour in response to air pollution notifications in Copenhagen. Soc. Sci. Med. 1991, 5, 621-626. [CrossRef]

151. Semenza, J.C.; Wilson, D.J.; Parra, J.; Bontempo, B.D.; Hart, M.; Sailor, D.J.; George, L.A. Public perception and behavior change in relationship to hot weather and air pollution. Environ. Res. 2008, 3, 401-411. [CrossRef] [PubMed]

152. Lercher, P.; Rudi Schmitzberger, R.; Walter Kofler, W. Perceived traffic air pollution, associated behavior and health in an alpine area. Sci. Total Environ. 1995, 1-3, 71-74. [CrossRef]

153. Rotko, T.; Oglesby, L.; Künzli, N.; Carrer, P.; Nieuwenhuijsen, M.J.; Jantunen, M. Determinants of perceived air pollution annoyance and association between annoyance scores and air pollution $\left(\mathrm{PM}_{2.5}\right.$, $\mathrm{NO}_{2}$ ) concentrations in the European EXPOLIS study. Atmos. Environ. 2002, 29, 4593-4602. [CrossRef]

154. Hino, A.A.F.; Reis, R.S.; Sarmiento, O.L.; Parra, D.C.; Brownson, R.C. Built environment and physical activity for transportation in adults from Curitiba, Brazil. J. Urban Health 2014, 3, 446-462. [CrossRef] [PubMed]

155. Gehl, J. Cities for People; Island Press: Washington, DC, USA, 2010.

156. Bühler, R.; Kunert, U. Trends und Determinanten des Verkehrsverhaltens in den USA und in Deutschland. Forschungsprojekt im Auftrag des Bundesministeriums für Verkehr, Bau und Stadtentwicklung; Deutsches Institut für Wirtschaftsforschung and VirginiaTech: Berlin, Germany, 2008. (In German)

157. Litmann, T.A. Land Use Impacts on Transport. How Land Use Factors Affect Travel Behavior; Victoria Transport Policy Institute: Victoria, Australia, 2015.

158. Pucher, J. Urban Travel Behavior as the Outcome of Public Policy. The Example of Modal-Split in Western Europe and North America. J. Am. Plan. Assoc. 1988, 4, 509-520. [CrossRef]

159. Yang, F.; Chen, L.; Cheng, Y.; Yao, Z.; Zhang, X. Urban public transport choice behavior analysis and service improvement policy-making. A case study from the metropolitan city, Chengdu, China. J. Appl. Stat. 2014, 4, 806-816. [CrossRef]

160. Köckler, H. Umweltbezogene Gerechtigkeit und Immissionsbelastungen am Beispiel der Stadt Kassel; Kassel Univ. Press: Kassel, Germany, 2008. (In German)

161. Umweltbundesamt. Umweltbedingte Krankheitslasten: Methodische Grundlagen des Environment Burden of Disease (EBD)-Ansatzes der WHO zur quantitativen Bewertung von Umweltbedingten Krankheitslasten. Chancen, Risiken und Grenzen der Methodik aus Naturwissenschaftlicher, Rechtlicher und Ethischer Perspektive (EBDreview). Available online: http://www.umweltbundesamt.de/sites/ default/files/medien/378/publikationen/umwelt_und_gesundheit_05_2015_methodische_grundlagen_ des_environment_burden_disease-ansatzes.pdf (accessed on 20 September 2016).

162. World Health Organization. Disease and Injury Country Estimates. Available online: http://www.who.int/ healthinfo/global_burden_disease/estimates_country/en/ (accessed on 20 September 2016).

163. Salim, M.M.H.; Schlünzen, K.H.; Grawe, D. Including trees in the numerical simulations of the wind flow in urban areas: Should we care? J. Wind Eng. Ind. Aerod. 2015, 144, 84-95. [CrossRef]

164. Mills, G. Progress toward sustainable settlements: A role for urban climatology. Theor. Appl. Clim. 2006, 1-3, 69-76.

(C) 2017 by the authors. Licensee MDPI, Basel, Switzerland. This article is an open access article distributed under the terms and conditions of the Creative Commons Attribution (CC BY) license (http:/ / creativecommons.org/licenses/by/4.0/). 